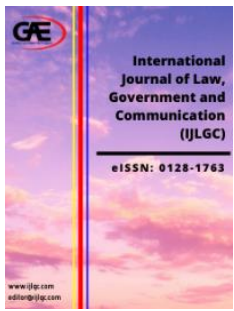

\author{
INTERNATIONAL JOURNAL OF LAW, \\ GOVERNMENT AND COMMUNICATION \\ (IJLGC) \\ www.ijlgc.com
}

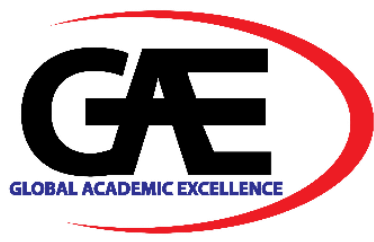

\title{
LEGAL AND POLICY BASIS FOR BAHASA ISYARAT MALAYSIA INTERPRETATION SERVICES
}

\author{
Muhamad Nadhir Abdul Nasir ${ }^{1 *}$, Alfa Nur Aini Erman Efendi ${ }^{2}$ \\ 1 Faculty of Arts and Social Sciences, University of Malaya (UM), Malaysia \\ Email: anndh91@gmail.com \\ 2 Independent Researcher \\ Email: alfa.e.efendi@gmail.com \\ Corresponding Author
}

\section{Article Info:}

Article history:

Received date: 30.09 .2020

Revised date: 09.10.2020

Accepted date: 25.10 .2020

Published date: 06.12.2020

\section{To cite this document:}

Nasir, M. N. A., \& Efendi, A. N. A. E (2020). Legal and Policy Basis for Bahasa Isyarat Malaysia Interpretation Services. International Journal of Law, Government and Communication, 5 (21),45-57.

DOI: $10.35631 /$ IJLGC.521005.

This work is licensed under CC BY 4.0

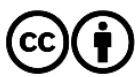

\begin{abstract}
:
There is an increasing need for Malaysian Sign Language interpreters or known as Jurubahasa Isyarat Malaysia (JBIM) to meet the economic, social, and cultural needs of persons who are deaf. To resolve the continuing lack of JBIM, the present paper addresses the legal and policy basis for the establishment of a government-owned and operated service system. We review several legal and government strategic documents, namely the Persons with Disabilities Act 2008, the Local Government Act 1976, the Policy for Persons with Disabilities 2007, the Action Plan for Persons with Disabilities 2016-2022, and the National Community Policy 2018. Although Bahasa Isyarat Malaysia (BIM) is recognized by the law beyond its status as an official language of deaf Malaysians and as part of their cultural identity, our analysis of these legal and policy documents do not suggest a tangible and proper mechanism for BIM interpretation service system. We assert the BIM interpretation services to be established and provided by local governments through collaboration with other federal government agencies and deaf people's organizations. We also discuss structural measures regarding recruitment and certification, job-related equipment, retirement fund as well as competitive wage. These four aspects are vital in ensuring the effectiveness and sustainability of the BIM interpretation services.
\end{abstract}

Keywords:

Bahasa Isyarat Malaysia, Deaf Community, Deaf People's Organizations, Interpretation Services, Local Government

\section{Introduction}

In the ASEAN Enabling Masterplan 2025: Mainstreaming the Rights of Persons with Disabilities, there are two specific key targets concerning national sign language which placed under the pillar of ASEAN Socio-Cultural Community (ASCC) as follows: 


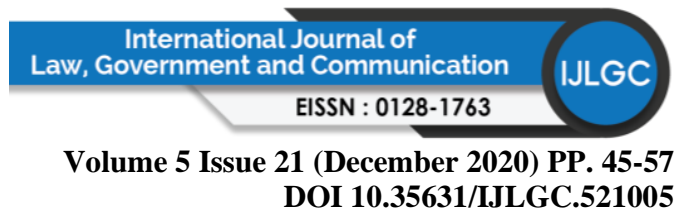

ASCC 15.1: Ensure the recognition of national sign language as the language for the deaf in all ASEAN Member States.

ASCC 15.2: Continuously develop and develop the usage of the national sign language in the area of education in all ASEAN Member States.

The national sign language of deaf Malaysians is Bahasa Isyarat Malaysia which hereinafter will be referred to as BIM. The present article, however, focuses on another vital component in interactions between deaf Malaysians and the majority hearing world - the sign language interpreters (also known as Jurubahasa Isyarat Malaysia or JBIM). For consistency, we refer to this profession as JBIM, whereas the service system is referred to as a BIM interpretation service system. Recent news spotlights the important roles of JBIM and their life stories (Kadir, 2020; Sinar Harian, 2020). A couple of news articles also quoted suggestion to encourage more Malaysians to learn BIM (Bernama, 2019, 2020).

Though the promotion of learning BIM is an admirable gesture to nurture recognition and respect toward BIM, there is an urgent need to increase the number of JBIM and properly institutionalize the BIM interpretation service system. Most Malaysians may be able to learn BIM, but for casual and basic conversations. As for the intense discussion, deaf persons require JBIM as service providers specializing in interpreting back and forth between BIM and verbal languages. According to the official website of the Malaysian Federation of the Deaf (https://www.mymfdeaf.org/jurubahasa-isyarat), the first certified BIM interpreter was Tan Yap Yang who received certification as an interpreter for the deaf from the United States. Before that, deaf persons have to rely on assistance from their family members and close friends. Starting in 1988, Persatuan Orang Pekak Kuala Lumpur initiated JBIM services for free.

Unfortunately, there is a very limited number of certified JBIM in the country to meet the ever-increasing demands of the deaf community (Harian Metro, 2017; Zolkifli, 2020). Hence, the present article seeks to address this problem by analyzing legal and policy documents to explore the basis for the establishment of a BIM interpretation service system. We begin this paper by reviewing relevant past literature follows by the explanation of research methodology. We present the analysis of the selected laws and policies under separate headings. Finally, we discuss the possibility of establishing a BIM interpretation service system as part of public social services operated by local governments and other relevant issues concerning JBIM's work condition.

\section{Literature Review}

Sign language interpreters remain as preferred services for most deaf persons and have huge potential to contribute to education, healthcare, legal, cultural and spiritual settings (Roberson, 2018). A review of the history of sign language interpreting profession in the United States highlights few factors influence the formalization of sign language interpreters as professions which are education for deaf children, recognition of American Sign Language (ASL) in the academia, professionalization movements and government monetary assistance (Ball, 2018). In the beginning, the interpreting work is carried out by family members and close friends who know the sign language, referred to as the 'helper model' (Roberson, 2018), in which deaf Malaysians also share a similar starting point. 


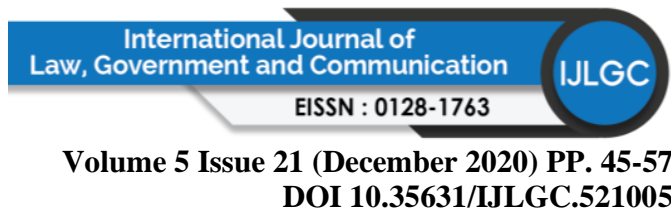

The question is; do countries, particularly developing and poor countries have and/or able to systemize sign language interpretation services? The development of sign language interpretation service systems depends on the economic, social, technological, and political conditions of a particular country (Russell, 2018). The rights of deaf persons to their language and culture besides access to communication and information are enshrined in the Convention on the Rights of Persons with Disabilities. But, translating and fulfilling these rights require monetary investment, especially from the government (Nasir \& Efendi, 2019) which many countries may not be able to because of the socio-economic circumstances of those countries (Martin, 2013).

Furthermore, the issue concerning the right of disabled persons to access social services overlaps with other social and economic rights (Axelsson \& Barrett, 2009, pp. 44) as evident in other discussion relating to disabled people's rights (Degener, 2016; Efendi, 2019; Efendi, Fadzil, \& Khoo, 2018; Heymann, Cassola, Raub, \& Mishra, 2013; Toebes, 2015). The development of systematic and accessible social services for disabled people requires the identification of stakeholders, their roles, mechanisms for working relationships between stakeholders, and legal enforcement (Axelsson \& Barrett, 2009, p. 60). The legal approach to regulate and ensure services for disabled people are also advocated by Chiriacescu (2006) and Eleweke (1999).

In Malaysia, we can see an increasing number of scholarly works regarding deaf persons, particularly in education. These work include issues relating to student development (Nor \& Rashed, 2018), vocational education (Minghat, Abdullah, Kamin, Hamid, \& Zulkifli, 2015), Islamic education (Seman, Omar, Yusoff, \& Abdullah, 2016), and sign language for religious practice (Khamaruddin, Muhamad, Raus, Yusoff, Hashim, Ja'afar, \& Rasdi, 2018; Rashid, Alias, Jomhari, Yusof, \& Haris, 2014). However, some studies tend to individualize the barriers confronted by deaf persons, either to communicate or in learning, such as focusing on linguistic competency (Seman et al., 2016), instead of interrogating the social, cultural, economic, and political structures that produce and reinforce such barriers.

We are not dismissing the barriers in 'self'. Instead, disability should be examined through the negative multi-relationships between the domain of self, society, and the environment anchored by inaccurate episteme (Nasir \& Efendi, 2018). For instance, a study by Toran, Yasin, Tahar, and Sujak (2009, pp. 23-24) on the experiences of disabled university students in a higher learning institution, find that deaf students face difficulty to meaningfully participate in lectures due to unavailability of JBIM. With regard to their access to social services, deaf people face obstacles such as attitudinal barriers, inability to afford assistive devices, difficulty getting sign language interpreters, lack of government funding, the stigma associated with acquiring social services, and inflexible service provision (Harris \& Bamford, 2001).

Besides that, more focus is given to the technological integration into services and support for disabled people. Undeniably, technological advancement can facilitate the work of sign language interpreters (Roberson, 2018; Steinberg, 2006) besides supporting the learning experience of deaf students (Samsudin, Tan, \& Yusof, 2018), but more research on the effectiveness and hindrances of using such technologies is needed (Roberson, 2018). The existence of technology does not automatically solve a communication barrier among deaf individuals. There are other issues such as the affordability and usability of the technology. 


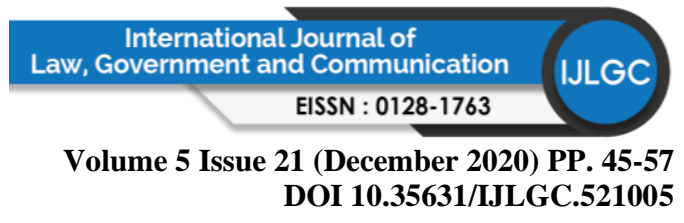

To build a proper sign language interpretation service system, we must consider the following components:

1. Access and equity of deaf persons to use sign language interpretation services;

2. Recognition of the roles and challenges of sign language interpreters;

3. Professionalization of sign language interpreters (training, certification, and protection of labor rights);

4. Establishment of a clear structure and mechanism to govern sign language interpretation services; and,

5. Provision of appropriate technologies.

Scholarly work relating to social model-based services also offers helpful insights that may apply to the structuring of the BIM interpretation service system. Public services, as Gibbs (2004) argues, must break away from the culture of welfare paternalism characterized by the following features: (1) hyper-focusing on categories, criteria, and diagnosis which missing the important stakes - the disabled people's needs; (2) refusing meaningful community- and self-oriented outcomes through the adoption of managerial approach and culture on the service provision process; (3) promoting the sense of disconnected and disembodied relationships between service providers and the users; and, (4) detaching the administrative and bureaucratic process of service development, implementation, and evaluation from all human and societal connections.

Equally important is user involvement in the service provision (Axelsson \& Barrett, 2009; Clare \& Cox, 2003). Yet, McDaid (2009) asserts that the discussion about user involvement tends to overlook four major concerns: (a) the capacity of the service users; (b) the service users' participation skills; (c) organizational culture that facilitates service user participation; and, (d) space or channel for service user participation (see also Car, 2004). Axelsson and Barrett (2009) in their report suggest embracing the twin-track approach, giving balance and connected focus on empowering disabled people as well as reconfiguring the social system. Also, McDaid's (2009) first two points above relate to the elements of social capital and social inclusion which should be considered in human-related services (Bates \& Davis, 2004).

\section{Methodology}

We conduct a policy analysis of selected legal and policy documents. These documents are the Persons with Disabilities Act 2008, the Local Government Act 1976, the Policy for Persons with Disabilities 2007, the Action Plan for Persons with Disabilities 2016-2022, and the National Community Policy 2018. We analyze the provisions and programs contained in these legal and policy documents using the following key phrases as a reference point: communication, community services, deaf, Bahasa Isyarat Malaysia, Jurubahasa Isyarat Malaysia, and social services. We obtain all of these documents from the internet.

All documents are in Malay language version, except for the Persons with Disabilities Act 2008 which we possess both Malay and English version. We conduct the policy analysis manually by reading through the whole content of the selected documents. We use the aforementioned key phrases to locate and copy relevant excerpts from these documents for analysis. We carry out the reading of the documents at least twice to avoid missing relevant 


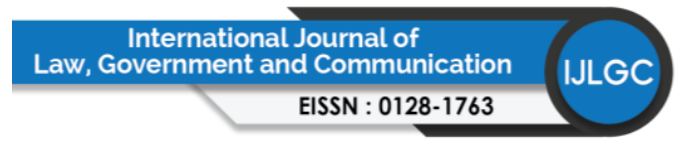

Volume 5 Issue 21 (December 2020) PP. 45-57 DOI 10.35631/IJLGC.521005

provisions or misunderstand the meaning. We analyze each document separately as shown in the next few sections.

We initiate this endeavor with the analysis of legal and policy texts for several reasons. First, notwithstanding the voices and experiences of deaf Malaysians, we want to identify and analyze the availability and the extent of existing legal and policy provisions for the establishment of the BIM interpretation service system. If there is evidence in these documents pointing to either 'community services' or 'social services', the present paper may shed some light on the gaps and opportunities which can be used as justification of such a system. Policy analysis is a useful tool to evaluate at least for three reasons: (a) to understand the socio-cultural and socio-political standing of the government on an issue - in other words, the episteme among policymakers; (b) to understand and analyze the mechanisms and question of power (including structure) in particular policy or program; and, (c) to gather evidence and suggest solutions for particular policy advocacy.

Though a policy analysis can uncover many abstract elements such as the discourse and philosophy besides the material contained in the texts (legal clauses, program, and targets), we realize policy analysis can only extract superficial textual materials. This is because the reality of policy implementation and law enforcement can be very different from what is stated in the texts. As such, we are against the generalization of the findings from the present study.

\section{Relevant Provisions in the Policy for Persons with Disabilities 2007}

The Policy for Persons with Disabilities 2007 contains a number of objectives grouped into fifteen areas. There are three relevant provisions in the Policy for Persons with Disabilities 2007 as the basis for the BIM interpretation service system. Those are Item 5.2 (accessibility), Item 5.8 (support services), and Item 5.10 (human resource development). Through the third objective under Item 5.2, the aim is to encourage the availability of and access to information and communication technologies. The policy recognizes the accessibility to information and communication technologies as one of the important aspects of disabled people's life. Furthermore, the policy contains a provision on the affordability of such technologies through the second objective under Item 5.8.

Turning to Item 5.8, the first objective aims to strengthen the support service mechanism for disabled persons according to their needs. This shows that the government has a clear goal, at least on the paper, to institutionalize a needs-oriented support system for disabled Malaysians. Meanwhile, according to the first objective under Item 5.10, the aim is to develop capacity and ensure a sufficient number of well-trained service providers to serve disabled people. From these provisions, the government has conceptualized three key components; the system, technologies, and human resources. Although the word 'Bahasa Isyarat Malaysia' or 'Jurubahasa Isyarat Malaysia' is nowhere to be found in the policy, the policy is written in a general and overarching sense to include the needs and rights of the deaf community in Malaysia.

Despite those three relevant provisions described above, we identify two critical gaps in the policy which are: (a) the absence of statement regarding the recognition and support for linguistic identity; and, (b) unclear allocation of responsibility to ensure the fulfillment of any or all objectives underlined in the policy. Any policy, as its nature, is written in a very broad 


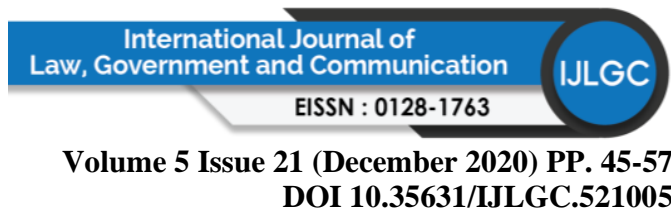

sense and usually, the details can be seen in the relating plans or strategies. As we soon discuss our analysis of the Action Plan for Persons with Disabilities 2016-2022 below, there is no clear provision to properly establish a BIM interpretation service system.

\section{Relevant Programs in the Action Plan for Persons with Disabilities 2016-2022}

The mention of the word 'Jurubahasa Isyarat Malaysia' can be identified under the first strategic core concerning accessibility for disabled persons. According to the third objective of the first strategic pillar underlined in the Action Plan for Persons with Disabilities 20162022, the Ministry of Communication and Multimedia is charged with the task to ensure all service providers to have support facilities such as JBIM and audio description. The program is designated as a long-term initiative, between 2016 until 2022. Other strategic partners for this initiative is the Commission of Communication and Multimedia, national nongovernmental organizations, and Modernizing Administration and Management Planning Unit (MAMPU).

To our knowledge and observation, there is yet to be any evaluation of whether this specific initiative has been achieved or otherwise. One positive point is that the action plan includes the contribution of non-governmental organizations in its implementation. Be that as it may, we are unable to extract any specificity of the initiative such as the financing model, structure of service system, and human resource development.

\section{Relevant Provisions in the Persons with Disabilities Act 2008}

The first key point from our analysis of the Persons with Disabilities Act 2008 is the recognition of BIM as a language and as an official language of deaf persons in Malaysia through Section 2. This means that BIM enjoys legal status as one of the languages in the country that potentially bring a positive impact in many areas of the deaf community's life. Besides that, the act also defines the term 'communication' to refer to various modes of communication, including BIM as well as accessible information and communication technologies.

The status of BIM is strengthened with specific provisions relating to its usage in the education of deaf persons. Paragraph (b) of subsection (3) under Section 28 makes it mandatory for the federal government and private education providers to facilitate the learning of BIM and promote the linguistic identity of deaf persons. The subsequent paragraph under the same subsection further extends the significance of BIM in education through the guarantee that deaf persons and deaf children (including those who are deafblind) learn using the most appropriate language and mode of communication.

Section 30 of the act which concerns the access of disabled persons to information, communication, and technology also outlines a few important points. First, Section 30 of the act recognizes the right of disabled persons to access information, communication, and technology on an equal basis with other citizens. Second, the federal government and information providers are legally required to provide information and communication in an accessible manner without delay and extra cost. Third, the federal government and the private sector must accept and facilitate the use of BIM in official transactions. The third point implicates the uses of JBIM and the possibility of some form of integration of BIM interpretation services into the official setting. 


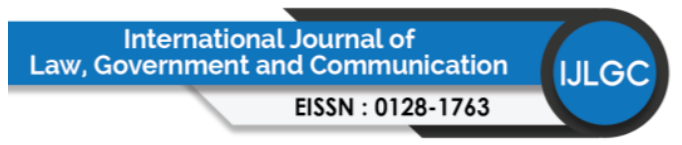

Volume 5 Issue 21 (December 2020) PP. 45-57 DOI 10.35631/IJLGC.521005

Besides that, we can observe the recognition of BIM and the rights of deaf persons to their language in Section 31. Section 31 of the act safeguards the right of disabled persons to cultural life, including accessing contents on televisions and other forms of entertainment. This section also guarantees the deaf community of the recognition and the support to promote BIM as well as deaf culture. This shows the recognition of BIM in the Persons with Disabilities Act 2008 is more than just as national sign language of deaf Malaysians.

Even though the law does not provide any general provision on specific service for BIM interpretation, subsection (2) of Section 33 requires the National Council for Persons with Disabilities, private healthcare providers, and non-governmental organizations to establish and expand social services for disabled persons according to individuals' needs and capabilities. In addition to that, Section 34 makes it mandatory for the National Council for Persons with Disabilities, the private sector, and non-governmental bodies to facilitate and promote the development of community support services. Though the National Council for Persons with Disabilities can be considered as an extension of the federal government as the council is chaired by a minister charged of social welfare, the law does not explicitly mention the government as part of the responsible parties in the two sections above.

Subtly, the government through the Persons with Disabilities Act 2008 is shifting the responsibility to establish and operate social services and community-based services to the private sector and non-governmental organizations. This signals that the federal government does not view social services and community-based support services as part of public services. Instead, the law provides the opportunity for the marketization of such services which presents a troubling notion. Relinquishing obligations to the private sector and nongovernmental organizations may seem like an effort to promote multi-sectoral collaboration, but the fact of the matter is, the government tries to minimize its monetary 'burden' and expect the community to self-sufficiently establish and sustain such services.

\section{Relevant Provisions in the Local Government Act 1976}

Section 101 of the Local Government Act 1976 provides us with a few useful legal provisions to establish social services or community support services for disabled people in their community. Subsection (d), for example, gives the additional power to local authorities to do work that can benefit the community within their jurisdiction. Besides that, subsection (v) extends the power of local authorities to take measures as they think necessary or bring benefit to public safety, health, and comfort. We argue the BIM interpretation service system is a basic and essential social service for deaf Malaysians. The needs and potential contribution of BIM interpretation services to deaf persons are limitless. Another important point that we should not dismiss is the benefit of such services for the communities; employers, shop owners, local entertainment providers, and so forth.

Subsection (dd) of Section 101 opens up the opportunity for local authorities to contract with other local authorities or persons to carry out work or enterprise and to take further actions for the work or enterprise according to the power given to local authorities. This justifies the engagement with JBIM for the BIM interpretation services as individual contractors. However, we affirm that BIM interpretation services should be institutionalized and integrated as part of local authorities' service structure, thus JBIM must obtain gainful employment as public servants and not just as 'independent contractors or freelancers'. Another gap of Section 101, particularly for subsection (d) and subsection (v) mentioned 


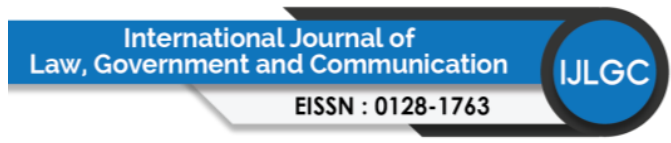

Volume 5 Issue 21 (December 2020) PP. 45-57

DOI 10.35631/IJLGC.521005

previously, there is no clear indication for local authorities to engage non-governmental organizations or a community for any work or services provided.

Even though Section 28 enables local governments to establish a committee for certain purposes with its membership can include other individuals, we see such a provision is limited. The act should contain new clauses and/or extend existing clauses on the direct participation of the community, particularly relating to the development and implementation of services for the communities they serve. We do not believe having one or two representatives of deaf persons in the committee is effective. Instead, we recommend direct participation of the deaf community in structuring and operating the services, not just as 'outside advisors' and 'potential clients'.

The Local Government Act 1976 also describes a few provisions relating to monetary aspects, including the power of local authorities to collect payment for services. Section 116, for instance, makes it possible for local authorities to charge a certain amount of payment. But, the section only focuses on building owners and renters. Through BIM interpretation services, we believe local authorities can charge a service fee to employers and event organizers, either government or private sector. The service fee can be one of the financial sources to sustain the BIM interpretation services. However, we oppose the idea of charging such a fee for deaf citizens without consulting the community.

\section{Relevant Programs in the National Community Policy 2018}

There are two relevant and important clusters in the National Community Policy 2018 pertaining to our topic. The fifth cluster in the aforementioned policy focuses on the care of children, senior citizens, disabled people, women, single mothers, and the poor. There are three strategies underlined for this goal; (a) increase the inclusivity of children, senior citizens, disabled people, women, single mothers, and the poor in the community development; (b) nurture care and compassion toward children, senior citizens, disabled people, women, single mothers, and the poor; and, (c) encourage strategic collaboration with other parties to assist these groups.

The seventh cluster, which focuses on social services, contains the following strategies; (a) nurture the spirit of volunteers; (b) encourage the establishment of social services according to the community's needs; (c) enhance existing social services; and, (d) encourage the networking of strategic cooperation between external parties and the community. Although the policy lays out good fundamentals for community support services, we are very concerned that the policy only encourages and narrowly emphasizes short-term programs instead of institutionally and structurally establishes a social service system that provides services continuously to the community.

Similar to Action Plan for Persons with Disabilities 2016-2022, the National Community Policy 2018 also put forward several targets for monitoring and evaluation purposes. We identify three relevant targets for this study; (i) level of satisfaction among special interest groups (as listed in the fifth cluster) regarding the care received from their community; (ii) level of inclusivity among special interest groups in the community development; and, (iii) level of satisfaction towards facilities and social services. 


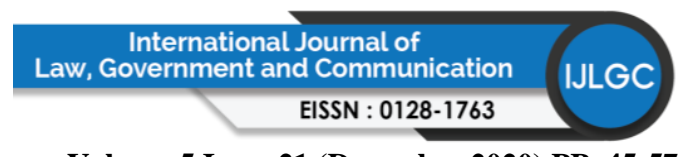

Volume 5 Issue 21 (December 2020) PP. 45-57 DOI 10.35631/IJLGC.521005

Again, the initiatives underlined in the policy shift most of the major obligations and structural issues to voluntary and community work. Furthermore, we assert the term inclusivity in the policy superficially addresses the diversity of needs without clear understanding, meaningful indicators, and empowering mechanisms, particularly for the disabled community.

\section{Discussion}

It seems there are no tangible or clear mechanisms for the BIM interpretation service system. However, the legal and government strategic documents do provide sufficient foundation, though very basic it may be, to establish proper formal BIM interpretation services as a part of public social services. We advocate for the BIM interpretation service system to be a part of public social services because, as argued by Axelsson and Barrett (2009), it is a right of the disabled person (which in this case referring to the deaf community) to access essential services to live on an equal basis as other citizens and should not be decided by the market.

There are two options; (1) the State Department of Social Welfare and its district branches become the anchor for the service system; or, (2) the local authorities become the operator of such services. We propose local governments to establish and operate the services with the cooperation of other federal government agencies such as the Ministry of Communication and Multimedia, Department of Social Welfare and Department of Workforce as well as deaf people's organizations, namely the Malaysian Federation of the Deaf (MFD).

We choose the second option because: (1) to ease the burden of responsibility shouldered by the Department of Social Welfare that manages and provides social assistance to disabled persons and other vulnerable groups in Malaysia; and, (2) to encourage and embrace crosssectorial collaboration and coordination for the inclusion of Malaysians with impairment and/or chronic illness. Though the service is organized and owned by local governments, the operation is carried out through collaboration between local governments and the deaf community. Deaf persons, alongside their hearing counterparts, must be hired to work in the service system, either as service administrators, quality assurance officers, BIM trainers, and other capacities pertinent to the services.

The National Council for Persons with Disabilities with the help of the National Council for Local Government can facilitate the establishment process of the service system in all states. The Malaysian Federation of the Deaf, on the other hand, can provide technical expertise to state and local governments as this organization has affiliate members throughout the country. On another note, local governments are answerable to their respective state governments. This means all state governments must also be engaged and consulted without overlooking local governments in federal territories. The establishment of BIM interpretation services also necessitates other structural measures. We identify four key areas that require attention:

1. Recruitment and certification.

2. Competitive wage and conducive working environment.

3. Retirement scheme for JBIMs.

4. Provision of job-related equipment. 


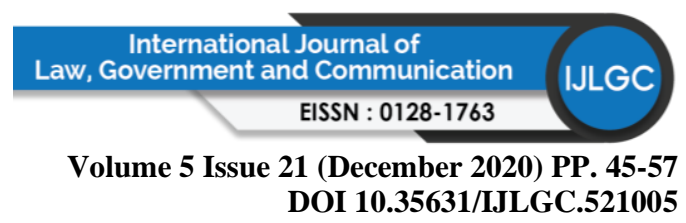

The four areas above are important for three reasons. First, JBIMs are professional service workers and they should be treated as such. Second, we must nurture a positive working environment for JBIMs, and their welfare and rights are protected. Finally, this is to attract more people, especially youngsters, to work in this sector.

First and foremost, we need to increase the number of JBIM. We suggest the number of JBIM is based on the number of deaf persons in a state or federal territory and its geographical size. We predict at least $50 \mathrm{JBIM}$ for each state and federal territory bringing the total number of 800 JBIM in Malaysia. This calls for a huge increase. However, the surge in quantity must not affect the quality of service delivery. A certification training is hence of utmost importance.

The local governments should collaborate with the Malaysian Federation of the Deaf in providing appropriate training to these interpreters. The Malaysian Federation of the Deaf should be given the authority to train, assess, and certify JBIM. The funding to organize the certification training is to be provided by the federal and state governments. We propose the recruitment and training of new interpreters to be carried out gradually and we expect the cost will decrease considerably in the long term. Online platforms can be utilized for training and examination.

Regarding their wage, we propose JBIM to be paid hourly for their services. For instance, if all 800 JBIMs are being paid MYR40.00 per hour and work for 6 hours a day for 22 days, the total amount of budget needed to pay for a monthly salary is MYR4.224 million. Besides that, we propose these interpreters should be provided with job-related equipment such as tablets or personal computers to enable them to provide video relay services to deaf clients. Provisions such as guaranteed competitive wage and equipment support will increase their motivation to work. It is also imperative to regulate the maximum working hour per day to avoid fatigue and stress among JBIMs which threaten their overall quality of life.

The final aspect is the retirement fund. Like anybody else, JBIMs also need long-term social safety saving for their old age. The federal and state governments with the consultation of the union of JBIMs must come out with a retirement plan for this group of professionals. To start, both federal and state governments can allocate some amount of money to establish the retirement fund. The funding allocation must also take into account existing or retired JBIMs who do not own a retirement fund.

Both federal and state governments must invest to properly set up and sustain these four areas. The federal government can also enact policies and schemes to encourage private investment without privatizing the services. We are strongly against privatizing the services because such a move may cause profit-racketeering and affect the access of the deaf community to use such services. The BIM interpretation service system must remain as a part of public social services with the direct participation of deaf persons as co-developers, coimplementers, and co-evaluators in all four aforementioned aspects. In other words, the participation of deaf persons is more than just 'users'.

\section{Conclusion}

On paper, BIM is recognized as a national language for Malaysians who are deaf. The recognition of BIM can be seen in education and cultural activities. Despite such recognition, 


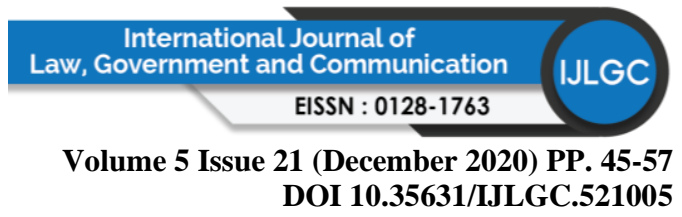

the deaf community still grapples with the lack of access to and a limited number of JBIM. Our analysis of the legal and policy documents reveals a very basic ground for the establishment of a proper BIM interpretation service system. There is also a troubling notion to institutionalize a neoliberal social service, which in principle, is essential for an adequate standard of living for deaf persons. Through this study, we harness the roles and duties of local governments in providing community-relevant services.

We also discuss other relevant aspects to effectively implement and sustain the service system. These aspects are recruitment and certification, a competitive salary, provision of job-related equipment, and retirement fund. We offer a few recommendations, including the financing of the service system, to be considered by Malaysian federal and state governments. We also emphasize the direct participation of the deaf community in the establishment, implementation, and monitoring of the BIM interpretation services. The deaf community and their representative organizations must be included in the system, not as passive recipients of the services, but as active contributors and users.

We are aware of the limitations of the present paper. Our discussion and proposals are only based on legal and policy texts which may not produce exactly as we envisioned in practice. Our recommendations are theoretical at best, thus further research is needed. Future research should extract qualitative data from the feedback and lived experiences of the service users (i.e. the deaf community) and JBIMs besides engaging with government officials. Although we are against the generalization of the findings from this study, we hope to spark critical and proactive discussion on this topic. Our goal, ultimately, is to advocate for better mechanisms and structures that enable meaningful and gainful living among Malaysians with impairment and/or chronic illness.

\section{References}

Axelsson, C., \& Barrett, D. (2009). Access to social services for persons with disabilities in the Middle East - Multi-stakeholder reflections for policy reform. Disability Monitor Initiative-Middle East. CBM \& Handicap International.

Ball, C. (2018). Historical foundations of a trust-based profession. In Roberson, L., \& Shaw, S., (eds.), Signed language interpreting in the 21st century: An overview of the profession. Washington DC: Gallaudet University Press.

Bates, P., \& Davis, F.A. (2004). Social capital, social inclusion and services for people with learning disabilities. Disability \& Society, 19(3), 195-207.

Bernama. (February 17, 2020). Pelajari bahasa isyarat, mudah komunikasi dengan OKU pendengaran (Online). Accessed from http://www.astroawani.com/beritamalaysia/pelajari-bahasa-isyarat-mudah-komunikasi-dengan-oku-pendengaran230872

Bernama. (December 23, 2019). Masyarakat disaran belajar, kuasai bahasa isyarat (Online). Accessed from http://www.astroawani.com/berita-malaysia/masyarakat-disaranbelajar-kuasai-bahasa-isyarat-225999

Car, S. (2004). Has service user participation made a difference to social care services?. London: Social Care Institute for Excellence.

Chiriacescu, D. (2006). Ensuring access of people with disabilities to social services: The need for regulatory mechanisms in South East Europe. Disability Monitor Initiative Handicap International Regional Office for South East Europe. Handicap International. 


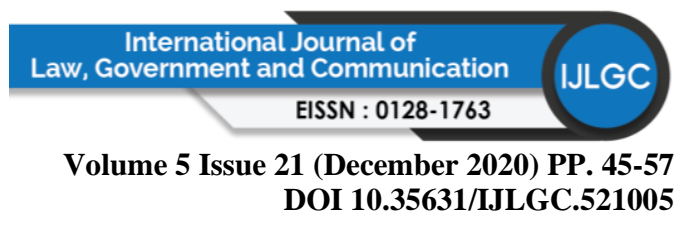

Clare, L., \& Cox, S. (2003). Improving service approaches and outcomes for people with complex needs through consultation and involvement. Disability \& Society, 18(7), 935-953.

Degener, T. (2016). Disability in a human right context. Laws, 5(3), 1-24.

Efendi, A.N.A.E. (2019). Akses, partisipasi dan pemerkasaan penjagaan kesihatan wanita kurang upaya di Lembah Klang (Master dissertation). Faculty of Arts and Social Sciences, University of Malaya.

Efendi, A.N.A.E., Fadzil, K.S., \& Khoo, Y.H. (2018). Better die at my own home than here in this hospital: Exploring challenges of women with disabilities in accessing healthcare in Malaysia. Sarjana, 33(1), 1-10.

Eleweke, C.J. (1999). The need for mandatory legislations to enhance services to people with disabilities in Nigeria. Disability \& Society, 14(2), 227-237.

Gibbs, D. (2004). Social model services: An oxymoron?. In Barnes, C., \& Mercer, G., (eds.), Disability policy and practice: Applying the social model, (pp. 144-159). Leeds: The Disability Press.

Harian Metro. (September 28, 2017). MyBIM aplikasi mudah alih bahasa isyarat (Online). Retrieved from https://www.pressreader.com/malaysia/harian-metro/20170928/ 281801399155578

Harris, J., \& Bamford, C. (2001). The uphill struggle: Services for Deaf and hard of hearing people - issues of equality, participation and access. Disability \& Society, 16(7), 969979.

Heymann, J., Cassola, A., Raub, A. \& Mishra, L. (2013). Constitutional rights to health, public health and medical care: The status of health protections in 191 countries. Global Public Health, 8(6), 639-653.

Kadir, S.A. (April 13, 2020). Eksklusif: Kisah Lee Bee dan bahasa tangannya. MalaysiaGazette. Accessed from https://malaysiagazette.com/2020/04/13/eksklusifkisah-lee-bee-dan-bahasa-tangannya/

Khamaruddin, S.R., Muhamad, N.A.F., Raus, N.M., Yusoff, A.M., Hashim, M., Ja'afar, N., \& Rasdi, M.N.A. (2018). Analisis keperluan pembangunan Bahasa Isyarat Malaysia bagi terminologi ibadah. International Journal for Studies on Children, Women, Elderly and Disabled, 4, 63-68.

Martin, R. (2013). Are human rights universal?. In Holder, C., \& Reidy, D. (eds.), Human rights: The hard questions. New York: Cambridge University Press.

McDaid, S. (2009). An equality of condition framework for user involvement in mental health policy and planning: Evidence from participatory action research. Disability \& Society, 24(4), 461-474.

Minghat, A.D., Abdullah, S.A., Kamin, Y., Hamid, M.Z.A., \& Zulkifli, M.F.M. (2015). Interest and confidence of hearing-impaired students toward vocational education: A preliminary study. Journal of Asian Vocational Education and Training, 8, 59-63.

Nasir, M.N.A., \& Efendi, A.N.A.E. (2019). Thematic analysis on the rights of disabled people to higher education. Journal of Education and Social Sciences, 12(1), 8-17.

Nasir, M.N.A., \& Efendi, A.N.A.E. (2018). The dawn of a new episteme: Proposing the neobiopsychosocial understanding of disability. South East Asia Journal of Contemporary Business, Economics and Law, 17(5), 26-34.

Nor, S.M., \& Rashed, Z.N. (2018). Peranan dan cabaran guru-guru pendidikan khas membentuk kemenjadian murid-murid masalah pendengaran dalam abad ke 21. JQSS - Journal of Quran Sunnah Education and Special Needs, 1(1), 1-8. 


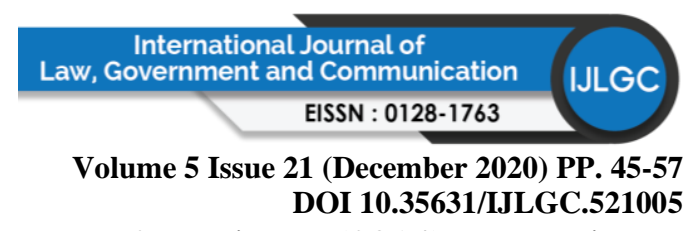

Rashid, S.M.M., Alias, N., Jomhari, N., Yusof, M.Y.Z.M., \& Haris, Z. (2014). Kepentingan Bahasa Isyarat Malaysia (BIM) dalam pengajaran perkara asas fardhu ain (PAFA) terhadap komuniti pekak. JuKu: Jurnal Kurikulum \& Pengajaran Asia Pasifik, 2(4), 27-33.

Roberson, L. (2018). Interpreting: An overview. In Roberson, L., \& Shaw, S., (eds.), Signed language interpreting in the 21st century: An overview of the profession. Washington, DC: Gallaudet University Press.

Russell, D. (2018). International perspectives on interpreting: Isn't everything just like at home? In Roberson, L., \& Shaw, S., (eds.), Signed language interpreting in the 21st century: An overview of the profession. Washington, DC: Gallaudet University Press.

Samsudin, M.R., Tan, T.G., \& Yusof, A.M. (2018). Impak aplikasi mudah alih terhadap tahap komunikasi pelajar pekak dan bisu. MALTESAS Multi-Disciplinary Research Journal, 3(1), 1-11.

Seman, N.H., Omar, M.C., Yusoff, A., \& Abdullah, M.Y. (2016). Analisis permasalahan pelajar cacat pendengaran dalam pembelajaran mata pelajaran pendidikan Islam di Malaysia. Jurnal Ilmi, 6, 105-124.

Sinar Harian. (April 13, 2020). Jurubahasa isyarat jadi tumpuan setiap kali siaran langsung COVID - 19. Sinar Harian. Retrieved from https://www.sinarharian. com.my/article/78728/KHAS/Koronavirus/Jurubahasa-isyarat-jadi-tumpuan-setiapkali-siaran-langsung-Covid-19

Steinberg, J.S. (2006). The use of existing videoconferencing technology to deliver video remote interpreting services for deaf vocational rehabilitation clients. In Morris, R.J., (ed.), Disability research and policy: Current perspectives, (pp. 39-68). New Jersey: Lawrence Erlbaum Associates Inc.

Toebes, B. (2015). Human rights and public health: Towards a balanced relationship. The International Journal of Human Rights, 19(4), 488-504.

Toran, H., Yasin, M.H.M., Tahar, M.M., \& Sujak, N. (2009). Sokongan dan halangan yang dihadapi pelajar-pelajar kurang upaya di sebuah institusi pengajian tinggi di Malaysia. ASEAN Journal of Teaching and Learning in Higher Education, 1(2), 18-29.

Zolkifli, F. (February 17, 2020). Johor kekurangan jurubahasa isyarat (Online). JohorKini. Accessed from https://www.johorkini.my/johor-kekurangan-jurubahasa-isyarat/ 